\author{
Marcin GALENT \\ Uniwersytet Jagielloński \\ m.galent@uj.edu.pl
}

\title{
POLAK I JEGO RODZINA W UNII EUROPEJSKIEJ
}

ABSTRACT The Pole and her/his family in the European Union

Contrary to most European countries, support for Polish membership of the European Union is still very high. Moreover, the level of trust towards the EU is constantly on the increase. The reason for the low level of social trust in Poland stems from the process which I term "re-familiarisation". This phenomenon is caused mainly by the shape of citizenship which has been accommodated in the last two decades. Its main traits consist in the withdrawal of the state and local authorities from the responsibility to guarantee basic social security. This withdrawal has recreated a "social dualism" in Poland. This dualism means that in some regions the place of the state has been successfully replaced by free market institutions, however there are also regions where these institutions are too weak to reduce this social insecurity effectively. As a consequence, where the free market is insufficient and the state absent, the Poles turns towards family ties. Since families are the main sources of security, trust is hence being built mainly within the family and other primary group frameworks which are closest. On the other hand, in tandem with the disappearance of the state from the social horizon and everyday experience of some Poles, they have begun to place their trust outside it. This outside space is the European Union, thanks to which Poles are experiencing an inflow of capital and investments as well as taking advantage of a new possibility structure brought about by the recently opened labour markets.

Słowa kluczowe: UE, obywatelstwo, zaufanie, dualizm społeczny, refamilizacja

Keywords: EU, citizenship, trust, social dualism, refamilisation 


\section{POLAKÓW KŁOPOTY Z ZAUFANIEM}

W przeciwieństwie do większości krajów w Europie, poparcie dla członkowstwa w Unii Europejskiej w Polsce utrzymuje się niezmiennie na bardzo wysokim poziomie, a większość Polaków jest zadowolona z dotychczasowych doświadczeń wynikających z dziesięcioletniej obecności w strukturach europejskich. Poza tymi powszechnie znanymi faktami odnotować również należy nowe, bardzo ciekawe zjawisko, jakim jest stale rosnący poziom zaufania do Unii Europejskiej. Co ważne, wiedza o tym zjawisku nie pochodzi już tylko z licznych i wielowymiarowych - wciąż jednak fragmentarycznych - badań jakościowych, ale została również potwierdzona przez reprezentatywne dla społeczeństwa polskiego badania ilościowe ${ }^{1}$.

Ta obserwacja jest niezwykle cenna głównie dlatego, że Polacy charakteryzują się jednym z najniższych poziomów zaufania w Europie. Dotyczy to nie tylko zaufania do organów państwa oraz instytucji władzy lokalnej, ale również tzw. zaufania uogólnionego, czyli także zaufania do swoich rodaków. Niemal wszyscy badacze zgadzają się, że jedną z najbardziej widocznych cech odróżniających Polaków od innych Europejczyków jest to, że krąg zaufania na ogół sprowadza się do członków własnej rodziny i bliskich znajomych. O ile $97 \%$ Polaków ufa najbliższej rodzinie, 90\% - znajomym, 89\% - dalszym krewnym i 84\% -współpracownikom, o tyle zaufanie do nieznajomych jest bardzo niskie ${ }^{2}$.

Bardzo niepokojącą cechą tego deficytu zaufania jest również to, że praktycznie w ogóle nie wykazuje oznak jakiejkolwiek poprawy. W Polsce z opinią, że „większości ludzi można ufać”, zgadzało się zaledwie 10,5\% w roku 2003 i 2005, odsetek ten nieznacznie wzrósł do $11,5 \%$ w roku 2007, 13,4\% w 2009 r., utrzymał się na tym poziomie do 2011 r., po czym spadł do 12,2\% w roku 20133. Widzimy więc, że zachodzące zmiany są minimalne, a ich wielkość utrzymuje się praktycznie w granicach błędu statystycznego.

Tak niski poziom zaufania lokuje nas na jednym z ostatnich miejsc w Europie. Dla porównania warto dodać, że te różnice są w niektórych przypadkach gigantyczne, w Wielkiej Brytanii oraz wszystkich krajach skandynawskich odsetek ufających jest trzy razy większy.

Biorąc pod uwagę ogólny wzrost poprawy warunków bytu i zamożności Polaków, ten uporczywie utrzymujący się niski poziom zaufania jest zatem wskaźnikiem, że z polskim społeczeństwem dzieje się coś złego. Zrozumienie, dlaczego tak się dzieje, jest dla badaczy społecznych wyzwaniem nie tylko poznawczym, lecz także praktycznym, bo

1 J. Kołodziej, Świadomość i rozumienie wartości europejskich w polskim społeczeństwie. Niepublikowane wystąpienie w ramach I Ogólnopolskiego Kongresu Europeistyki „Polska w procesie integracji europejskiej - dekada doświadczeń", Warszawa, 18-20 IX 2014.

2 CBOS, Komunikat z badań, BS/33/2012, Zaufanie spoteczne, Warszawa, III 2012.

3 J. Czapiński, 6.3. Kapitat spoteczny, „Conterporary Economics” 2013, Vol. 7, Special Issue: Diagnoza spoteczna 2013. Warunki i jakość życia Polaków, s. 285, [online] http://dx.doi.org/10.5709/ ce.1897-9254.110. 
może przyczynić się do znalezienia odpowiedzi na pytanie, dlaczego kondycja polskiego społeczeństwa w tym ważnym wymiarze nie ulega poprawie i co należałoby zrobić, żeby to zmienić. Poszukiwanie odpowiedzi na pytanie, co powoduje taki stan rzeczy, jest tym bardziej frapujące, że wzrost zaufania do Unii Europejskiej pokazuje, że nie jesteśmy skazani na żaden fatalizm i zmiana jest jednak możliwa. Tym samym daje nadzieję na to, że Polacy nie są na ten brak zaufania skazani po wsze czasy i że uwarunkowania historyczne i współczesne realia są możliwe do przezwyciężenia.

\section{ZAUFANIE: ZASADNICZY SKŁADNIK KAPITAŁU SPOŁECZNEGO}

Zaufanie, ten fundament spoteczeństwa $a^{4}$, to składnik większej puli zasobów dostępnych w każdym społeczeństwie i nazywanych ogólnie kapitałem społecznym. Kapitał społeczny w ostatnich dwóch dekadach stał się przedmiotem szczególnego zainteresowania w naukach społecznych, co znalazło odzwierciedlenie w obfitości ujęć teoretycznych, badań empirycznych i wielości wątków w dyskursie publicznym ${ }^{5}$. Ten gwałtowny wzrost zainteresowania skłonił nawet niektórych autorów do niepozbawionej pewnego sarkazmu uwagi, że kapitał społeczny: Uznawany jest za lekarstwo na wiele dolegliwości nowoczesnego spoteczeństwa i postrzegany jako cudowne spoiwo przyczyniajace sie do odczuwania większego szczęścia oraz efektywniejszego dziatania gospodarek i demokracji ${ }^{6}$. Nie wchodząc tutaj w szczegółowe rozważania dotyczące różnic w poszczególnych ujęciach, podkreślić należy, że w sumie panuje ogólna zgoda co do tego, że kapitał społeczny to istota społeczeństwa obywatelskiego, które dzięki niemu nabywa wysokiej zdolności do zbiorowej kooperacji i jest przez to w stanie efektywnie się rozwijaćt.

W kontekście niniejszych rozważań ważne jest przede wszystkim rozróżnienie trzech funkcjonalnych typów kapitału społecznego: wiążącego (bonding), pomostowego (bridging) i łączącego (linking). Kapitał społeczny wiążący rozumiany jest jako więź skierowana do wewnątrz, ekskluzywistyczna, wzmacniająca homogeniczność grupy, a tym samym zaufanie w obrębie grupy. Kapitał społeczny pomostowy z kolei skierowany jest na zewnątrz, jest inkluzywistyczny, przyczynia się do heterogenizacji grupy, łączy grupy i przyczynia się do zwiększania zaufania wobec ludzi spoza własnej grupy. Jak pisał Putnam: Zbudowanie pomostowego kapitatu spotecznego wymaga przekroczenia

P. Sztompka, Zaufanie. Fundament spoteczeństwa, Kraków 2007.

5 Zob.: P. Bourdieu, The Forms of Capital, [w:] Handbook of Theory and Research for the Sociology of Education, red. J. Richardson, New York 1986; J. Coleman, Social Capital in the Creation of Human Capital, „American Journal of Sociology” 1988, Vol. 94, Supplement, [online] http://dx.doi. org/10.2307/2780243; F. Fukuyama, Zaufanie. Kapitat spoteczny a droga do dobrobytu, przet. A. i L. Śliwa, Warszawa-Wrocław 1997; D. Halpern, Social Capital, Cambridge 2005; D.R. Putnam, Demokracja w dziataniu. Tradycje obywatelskie we wspótczesnych Wtoszech, przeł. J. Szacki, Kraków 1995, Demokracja.

6 L. Halman, L. Ruud, Social Capital in Contemporary Europe: Evidence from the European Social Survey, „Portuguese Journal of Science” 2006, Vol. 5, nr 1, s. 65, [online] http://dx.doi.org/10.1386/ pjss.5.1.65/1.

7 J. Czapiński, 6.3. Kapitat spoteczny, s. 285. 
naszych spotecznych, politycznych i zawodowych tożsamości ${ }^{8}$. Najmniej uwagi w polskiej literaturze przedmiotu poświęca się ostatniemu rodzajowi kapitału społecznego, który zdaniem Halperna: Jest pewna odmiana kapitatu pomostowego, który dotyczy relacji wta$d z y$ i stanowi pionowy pomost pomiędzy asymetrycznie roztożonymi zasobami i dostępem do wtadzy. [...] Brak tego rodzaju kapitatu oznacza spoteczeństwo, gdzie dostęp do wtadzy $i$ zasoby sa zastrzeżone dla pewnych środowisk, klik i chronionych enklaw?.

Polskie społeczeństwo jest bardzo bogate w kapitał wiążący, czerpany głównie z grup pierwotnych, natomiast ubogie w kapitał pomostowy, czyli taki, który umożliwia efektywną kooperację pomiędzy środowiskami społecznymi, oraz łączący, czyli taki, który umożliwia organizującym się obywatelom wpływ na struktury władzy instytucjonalnej.

Wydaje się, że słabość kapitału społecznego w społeczeństwie polskim jest już bardzo dobrze zdiagnozowana i opisana. Włożono również wiele wysiłku w to, aby wydobyć na światło dzienne przyczyny takiego stanu rzeczy. Wyjaśnienia te jednak mieszczą się głównie w perspektywie socjologii historycznej, w której obrębie wskazuje się na wynikające z przeszłości uwarunkowania wpływające na obecną kondycję społeczeństwa polskiego. Na ogół upatruje się tutaj winy w dziedzictwie realnego socjalizmu lub wskazuje na pozostałość śladów społeczeństwa postfeudalnego. Katalog tych uwarunkowań jest dosyć spory: refeudalizacja zapoczątkowana w XVI w., zabory, wojny, komunizm, rozpad systemu i związane z tym załamanie hierarchii społecznych, degradacja byłych decydentów, lustracja ujawniająca skalę inwigilacji przez policję polityczną i związana z nią kompromitacja autorytetów, transformacja od gospodarki centralnie planowanej do rynkowej. Diagnozy te oparte są głównie na makroanalizach, w których tego rodzaju problemy społeczne ukazywane są na tle głębokich zmian społecznych, nieuchronnie wyzwalających niechciane, ale również nieuniknione patologie, które w dłuższym okresie również nieuchronnie zostaną przezwyciężone ${ }^{10}$.

Mniej natomiast jest badań empirycznych dotyczących wpływu współczesnych mechanizmów społecznych na kształtowanie się kapitału społecznego, a już szczególnie niewiele jest badań, które przyjmowałyby oddolną perspektywę robotników, rolników, bezrobotnych, migrantów, czyli wszystkich tych, którzy w codziennych praktykach reagują na te makrostrukturalne zmiany. To przecież ci właśnie aktorzy społeczni, poprzez dokonywanie wyborów, w jak sposób budować strategie przetrwania i realizacji własnych interesów, odciskają piętno na globalnych cechach polskiego społeczeństwa ${ }^{11}$.

R.D. Putnam, Bowling Alone. The Collapse and Revival of American Community, New York 2000, s. 411.

9 D. Halpern, Social Capital, s. 25.

10 Np.: P. Sztompka, Trauma wielkiej zmiany. Spoteczne koszty transformacji, Warszawa 2000; M. Ziółkowski, Przemiany interesów i wartości spoteczeństwa polskiego. Teorie, tendencje, interpretacje, Poznań 2000, Pierwsza dekada niepodlegtości. Próba socjologicznej syntezy, red. E. Wnuk-Lipiński, M. Ziółkowski, Warszawa 2001; Trzy Polski. Potencjat i bariery integracji z Uniq Europejska. EU-monitoring III, red. J. Hausner, M. Marody, Warszawa 1999; Obszary tadu i anomii. Konsekwencje i kierunki polskich przemian, red. A. Miszalska, A. Piotrowski, Łódź 2006.

11 M. Buchowski, The Specter of Orientalism in Europe: From Exotic Other to Stigmatized Brother, „Anthropological Quarterly” 2006, Vol. 79, nr 3, s. 467, [online] http://dx.doi.org/10.1353/ anq.2006.0032. 
Wiele znakomitych prac, które takie założenia teoretyczne i metodologiczne zaadaptowało, niestety tej luki w całości nie wypełnia ${ }^{12}$.

Niniejszy artykuł oparty jest na projekcie badawczym, którego głównym założeniem było dotarcie do konkretnych, a nie wyabstrahowanych aktorów życia społecznego, aktorów działających w swoich naturalnych środowiskach. Celem takiego podejścia metodologicznego było uchwycenie relacji pomiędzy strukturami, w których obrębie funkcjonują aktorzy społeczni, a ich sprawczością, czyli ich zdolnością do przekształcania tych struktur. Jest to mechanizm, który Anthony Giddens nazywa strukturacją ${ }^{13}$.

Obserwacja aktorów w ich naturalnym środowisku oraz rekonstrukcja symbolicznego modelu świata, w którym operują, ma na celu uchwycenie kilku nakładających się na siebie problemów badawczych. Są to m.in. pytania o to, na ile tradycyjne struktury społeczne wykształcone w procesie długiego trwania są reprodukowane w codziennych rutynowych działaniach, na ile te struktury poddawane są refleksyjnej zmianie i detradycjonalizacji ${ }^{14}$, na ile są efektem internalizacji aktualnych hegemonicznych dyskursów społecznych, a na ile wynikają po prostu z sytuacyjnych kalkulacji i pragmatyzmów niezliczonych jednostkowych wyborów. Ta wiedza jest kluczem do uchwycenia mechanizmów zmiany społecznej wynikających z praktyki codziennych działań. To na podstawie tych działań nadbudowywane są nowe struktury, które potem wyznaczają kontekst dla przyszłych wzorów postępowania.

Schodząc na poziom operacjonalizacji tych teoretycznych rozważań, pytanie, na jakie chcę udzielić odpowiedzi w tym artykule, brzmi: jak wytłumaczyć fakt, że zaufanie w społeczeństwie polskim utrzymuje się na wyjątkowo niskim poziomie, podczas gdy jednocześnie rośnie zaufanie do Unii Europejskiej? Innymi słowy, jak to jest, że pomimo iż kapitał społeczny w Polsce ma wybitnie wiążący charakter, to odległa i pozbawiona legitymizacji demokratycznej instytucja staje się Polakom coraz bliższa. Przy czym, muszę zastrzec, potraktowanie realiów Polski lokalnej jako soczewki skupiającej zasadnicze problemy naszej krajowej współczesności nie oznacza oczywiście, że przez ten pryzmat możliwe jest pokazanie całej złożoności polskiego społeczeństwa. Nawet przy tak wąsko zarysowanym problemie badawczym. Niemniej jednak jestem głęboko przekonany, że wiele obserwacji pochodzących z naszych badań ma potencjał eksplanacyjny wykraczający poza te konkretne lokalne wspólnoty, a niektóre wnioski sformułowane w tym tekście można będzie ekstrapolować również na inne środowiska.

12 Zob.: Oblicza lokalności. Tradycja i wspótczesność, red. J. Kurczewska, Warszawa 2006; Wyciskanie brukselki? O europeizacji spoteczności lokalnych na pograniczach, red. J. Kurczewska, H. Bojar, Warszawa 2009; J. Kurczewski, red. Lokalne wzory kultury politycznej. Szkice ogólne i opracowania monograficzne, red. J. Kurczewski, Warszawa 2007; J. Kurczewski, M. Cichomski, K. Wiliński, Wielkie bazary warszawskie. Środowisko spoteczne, kultura i problem spoteczny, Warszawa 2010, Obyczaje, Prawo i Polityka, Życie Codzienne; Socjologia pojednania, red. J. Kurczewski, Kraków 2012, Seria Wydawnicza Polskiego Towarzystwa Socjologicznego.

13 A. Giddens, Stanowienie spoteczeństwa. Zarys teorii strukturacji, przeł. S. Amsterdamski, Poznań 2003.

14 Tenże, Życie w spoteczeństwie posttradycyjnym, [w:] U. Beck, A. Giddens i S. Lash, Modernizacja refleksyjna. Polityka, tradycja i estetyka w porządku spotecznym nowoczesności, przeł. J. Konieczny, Warszawa 2009, Socjologia Wspótczesna. 
Wracając zatem do zarysowanego wyżej pytania badawczego, przyczyn takiego stanu rzeczy należy dopatrywać się w nakładaniu się na siebie trzech procesów. Przy czym nakładanie to wykazuje moim zdaniem znamiona związku przyczynowo-skutkowego. I tak, bezpośrednim powodem utrzymywania się wysokiego zaufania do grup pierwotnych przy jednoczesnym niskim zaufaniu do uogólnionych innych jest głównie to, że znaczne segmenty polskiego społeczeństwa przechodzą proces, który nazywam refamilizacją. Refamilizacja ta wynika głównie z odtwarzania się tzw. dualizmu społecznego. Z kolei ten dualizm społeczny spowodowany jest, poza konsekwencjami wynikającymi z wielowiekowej peryferyjnej pozycji Polski i różnorakimi problemami powstającymi przy zmaganiu się $z$ nowoczesna forma ${ }^{15}$, specyficzną dla Polski realizacją modelu idei obywatelstwa. Chodzi o to, że ta idea w polskich realiach w istotny sposób odbiega od wzoru rozwiniętego w krajach Europy Zachodniej. Wzoru, który pomimo różnych kryzysów jest wciąż jednym z konstytutywnych elementów ładu społecznego tych krajów.

\section{TRZY WYMIARY IDEI OBYWATELSTWA W EUROPIE}

Mówiąc o idei obywatelstwa, nie mam tu na myśli idei społeczeństwa obywatelskiego, bardzo żywej w polskiej myśli społecznej. Społeczeństwo obywatelskie definiowane jest, najogólniej rzecz ujmując, jako sfera aktywności społecznej, która nie należy ani do władzy państwowej czy samorządowej, ani do sfery działań rynkowych. Jest natomiast obszarem dobrowolnej obywatelskiej działalności: wolontariatu, stowarzyszeń, zrzeszeń, ruchów społecznych itp. Idea obywatelstwa, którą mam na myśli, leży raczej u podstaw tych trzech obszarów życia społecznego i polega nie tylko na formalnej, ale również realnej gwarancji realizacji praw i obowiązków każdego członka wspólnoty politycznej. Zakres tych praw i obowiązków rozumiem tutaj zgodnie z klasycznym ujęciem zaproponowanym przez Thomasa $\mathrm{H}$. Marshalla w połowie XX w. Marshall twierdzi, że na współczesne obywatelstwo składają się trzy zasadnicze wymiary: cywilny, polityczny i społeczny. Jego zdaniem narodziny i kształtowanie się nowoczesnego społeczeństwa w dużej mierze pokrywają się z upowszechnianiem i umacnianiem tych trzech wymiarów obywatelstwa ${ }^{16}$.

Najpierw upowszechnił się wymiar cywilny, czyli gwarancja praw własności, wolności osobistej, wolności wyznania, wolności słowa, prawa do sprawiedliwego sądu, do prywatności, tajemnicy korespondencji itp. Kolejnym etapem była realizacja wymiaru politycznego, czyli wprowadzanie kontroli społecznej nad władzą. Na ogół mowa jest w tym kontekście o procesie demokratyzacji, w którym od czasów, gdy wpływ na władzę miały tylko wąskie elity, społeczeństwa europejskie przeszły do sytuacji, w której każdy dorosły członek wspólnoty politycznej, niezależnie od statusu, majątku czy płci,

15 J. Sowa, Fantomowe ciato króla. Peryferyjne zmagania z nowoczesna formą, Kraków 2011, Horyzonty Nowoczesności, 90.

16 T.H. Marshall, Citizenship and Social Class, [w:] Citizenship. Critical Concepts, red. B. Turner, P. Hamilton, London-New York 1994. 
ma równy głos $\mathrm{w}$ wyborach władz różnego szczebla. Trzeci wymiar obywatelstwa ma charakter społeczny. Oznacza to, że wszyscy członkowie wspólnoty powinni być objęci siatką bezpieczeństwa materialnego. Taka siatka bezpieczeństwa ma spełniać dwie funkcje. Jedna jest oczywista i polega na ochronie członków wspólnoty politycznej przed biedą i wykluczeniem. Druga jest mniej oczywista, często poznawana, a nawet kwestionowana, szczególnie w Polsce, i polega na tym, żeby zagwarantować, aby każdy z członków wspólnoty posiadał odpowiednie zasoby do tego, żeby mógł skutecznie realizować swoje prawa obywatelskie wynikające z pierwszego i drugiego wymiaru. Innymi słowy, nie ma społeczeństwa liberalno-demokratycznego ze sprawnie działającą gospodarką wolnorynkową i silnym społeczeństwem obywatelskim bez obywateli zabezpieczonych przed ryzykiem. Tym bardziej że współczesne społeczeństwo postindustrialne jest właśnie społeczeństwem ryzyka ${ }^{17}$. W takim posttradycyjnym, zindywidualizowanym społeczeństwie europejskim każda jednostka jest narażona na co najmniej trzy rodzaje ryzyka socjalnego. Po pierwsze, ryzyko klasowe, wynikające z dynamiki zmian rynkowych i technologicznych, w wyniku których każdy może znaleźć się bez pracy i tym sposobem bez środków do życia. Po drugie, ryzyko wynikające z cyklu życiowego: stanu dzieciństwa, macierzyństwa/tacierzyństwa lub wieku podeszłego, czyli z sytuacji, w których na ogół każdy człowiek potrzebuje pomocy innych. I po trzecie, ryzyko międzygeneracyjne, czyli wynikające z urodzin w takiej, a nie innej rodzinie ${ }^{18}$. Jak będę się potem starał pokazać, te ryzyka kumulują się w Polsce głównie w regionach odległych od miejskich metropolii i dotykają szczególnie boleśnie lokalne społeczności.

Marshall podkreślał, że po to, aby te wszystkie trzy elementy były wprowadzane w życie realnie, a nie posiadały tylko wartość deklaratywną, konieczne jest dbanie o każdy z nich. Jego zdaniem demokratycznego ideału władzy nie da się zrealizować, jeśli znaczna część społeczeństwa będzie wykluczona w wymiarze socjalnym. Ludzie biedni, walczący o przetrwanie, nie będą w stanie efektywnie współtworzyć demokratycznej władzy. Nie będą w stanie angażować się w jej współtworzenie, kontrolowanie, dbanie o przejrzystość i odpowiedzialność, a tym samym udzielać legitymizacji i utożsamiać się z nią. Podobnie zagwarantowanie wyłącznie praw socjalnych, bez przyznania praw politycznych, nie przełoży się na demokratyczne rządy, dobre społeczeństwo obywatelskie czy sprawne działanie gospodarki ${ }^{19}$.

Oczywiście relacje pomiędzy tymi trzema aspektami są dynamiczne i mają charakter historyczny. W różnych krajach europejskich każdy z tych trzech wzajemnie powiązanych i współoddziaływających wymiarów obywatelstwa był i jest realizowany w różnym stopniu i zakresie, przez co wszędzie praktyczna realizacja idei obywatelstwa przyjmuje swój specyficzny kształt. W każdym kraju inaczej rozkładają się prawa i obowiązki

17 U. Beck, Spoteczeństwo ryzyka. W drodze do innej nowoczesności, przeł. S. Cieśla, Warszawa 2004, Spoteczeństwo Wspótczesne.

18 G. Esping-Andersen, Spoteczne podstawy gospodarki postindustrialnej, przeł. R. Włoch, Warszawa 2010, s. 56-60, Wspótczesna Polityka Spoteczna, 1.

19

T.H. Marshall, Citizenship... 
z obywatelstwem związane. I tak, kwestie wymiaru cywilnego są w oczywisty sposób $\mathrm{w}$ różny sposób rozumiane i regulowane w różnych społeczeństwach europejskich. $\mathrm{Na}$ różne sposoby rozumie się i realizuje np. idę̨ wolności sumienia. W niektórych krajach uznano, że konieczna jest kompletna laicyzacja państwa, tak jak ma to miejsce we Francji, w innych, że religia państwowa powinna pozostać uprzywilejowana, a hierarchom Kościoła należy zagwarantować realny wpływ na władzę ustawodawczą, tak jak jest w Wielkiej Brytanii, gdzie biskupi zasiadają w Izbie Lordów. Prawa anglikanów są zatem zdecydowanie większe niż np. katolików. Podobnie jest z wymiarem politycznym, w którym pomimo daleko posuniętej harmonizacji wciąż istnieją pewne lokalne swoistości, jak choćby szwajcarskie przywiązanie do demokracji bezpośredniej i jej narzędzia, czyli referendum. Wskazywałoby to na to, że Szwajcarzy posiadają relatywnie dużo praw politycznych. W innej sytuacji znajdują się Belgowie, którzy wraz z prawem do partycypacji w demokratycznych wyborach wprowadzili również obowiązek obligatoryjnego głosowania. Kto odmawia udziału w wyborach, karany jest grzywną. Stosunkowo wiele różnic istnieje również w sposobie realizacji trzeciego wymiaru obywatelstwa, czyli społecznego. Pomijając różnice na poziomie każdego państwa, a nawet na poziomie subpaństwowym, bo np. w Szkocji, która jest częścią Zjednoczonego Królestwa, obywatelstwo społecznego realizowane jest inaczej niż w Anglii, badacze na ogół zgadzają się, że można pod tym względem wyodrębnić w Europie co najmniej trzy modele regionalne: anglosaski, skandynawski i kontynentalny ${ }^{20}$.

Polska wraz z innymi krajami, które znalazły się za żelazną kurtyną, poszła pod tym względem zupełnie inną drogą. Mniej więcej w tym samym czasie, w którym Thomas H. Marshall opublikował swój esej, Polska weszła na ścieżkę modernizacji socjalistycznej. Jej specyfika polegała na tym, że do minimum zredukowano wymiar pierwszy, czyli cywilny, oraz drugi, czyli polityczny, doprowadzając jednocześnie do przerostu wymiaru trzeciego, czyli społecznego. W realnym socjalizmie odmówiono obywatelom $\mathrm{w}$ wielkim stopniu praw cywilnych, niemal zlikwidowano wszystkie prawa polityczne, próbowano natomiast zagwarantować pełne zatrudnienie oraz pełne zabezpieczenie przed ryzykiem.

\section{POLSKI MODEL IDEI OBYWATELSTWA}

Upadek systemu i przyjęty następnie model transformacji odwróciły te zdeformowane proporcje. Szybko odbudowano polityczny wymiar obywatelstwa oraz przywrócono elementarne standardy wymagane do realizacji jego cywilnego wymiaru. Inaczej sprawa się ma z wymiarem społecznym obywatelstwa. W tym przypadku doszło do zasadniczej redukcji praw i obowiązków z nim związanych, polegającej przede wszystkim na wycofaniu się państwa z pełnienia wielu funkcji ważnych z punktu widzenia bezpieczeństwa socjalnego, a także z dążenia do obniżenia poziomu redystrybucji zasobów w obrębie społeczeństwa i zdaniu się w tej materii na nieuregulowany rynek. Taka strategia

20 G. Esping-Andersen, The Three Worlds of Welfare Capitalism, Princeton 1990. 
wychodzenia z realnego socjalizmu przełożyła się na to, że Polacy mają aktualnie bardzo wątłe prawa wynikające $\mathrm{z}$ obywatelstwa społecznego i w bardzo ograniczonym zakresie mogą liczyć na mechanizmy bezpieczeństwa gwarantowane uprzednio przez państwo w sytuacji, kiedy któreś z ryzyk się materializuje. Zilustruję to przykładem poziomu wsparcia przez państwo w sytuacji bezrobocia. Według danych OECD polskie społeczeństwo przeznacza na pomoc dla bezrobotnych zaledwie $0,3 \% \mathrm{PKB}$, podczas gdy w Belgii jest to dwanaście razy więcej (3,7\%), w Hiszpanii jedenaście razy więcej $(3,5 \%)$, w Estonii prawie cztery razy więcej $(1,1 \%)$, w Słowacji ponad dwa razy więcej $(0,7 \%)$, a w postrzeganych jako państwo, gdzie obywatelstwo ma bardzo słabo rozwinięty wymiar społeczny, Stanach Zjednoczonych - trzy razy więcej $(0,9 \%)^{21}$. Wraz z likwidacją praw wynikających z realizacji społecznego wymiaru obywatelstwa zmniejszyły się również obowiązki z tym związane.

\section{PROCESY DUALIZACJI SPOŁECZNEJ}

Taki model transformacji spowodowal, ż w Polsce do pewnego stopnia odtwarza się sytuacja, która diagnozowana była już na naszych ziemiach pod koniec XIX w. Diagnoza ta wskazywała na to, że na doszło wtedy do tzw. dualizacji społecznej. Polegała ona na tym, że w zasadniczo agrarnym społeczeństwie, w którym dominowały postfeudalne stosunki społeczne, w niektórych miastach doszło do szybkiej i gwałtownej industrializacji. Tym sposobem społeczeństwo polskie weszło w stan polaryzacji, gdzie w morzu postfeudalnego, tradycyjnego społeczeństwa agrarnego wyrastać zaczęły wyspy nowoczesności ${ }^{22}$. To w tym właśnie czasie Jan Popławski, publicysta i jeden z głównych twórców ideologii narodowo-demokratycznej, opublikował w "Głosie” słynny esej, w którym stwierdził, że polskie społeczeństwo to „dwa narody”, jeden to lud, a drugi to uprzywilejowani ${ }^{23}$.

Prawdopodobnie podziały w Polsce Anno Domini 2014 są dużo bardziej złożone i skomplikowane, niemniej jednak, biorąc pod uwagę relatywnie dynamiczną i pozytywną zmianę, jaka zaszła w ostatniej dekadzie w dużych miastach ${ }^{24}$, te wielowymiarowe podziały mogą się uprościć, ponowna polaryzacja zintensyfikować i nabrać bardziej realnego kształtu.

Tym bardziej że zajmujemy się tutaj nie obiektywnymi wskaźnikami kondycji materialnej, ale świadomością społeczną, w której poczucie relatywnej deprywacji może mieć znacznie poważniejsze konsekwencje niż zwiększony dostęp do różnego rodzaju

21 OECD, Public unemployment spending, [online] http://www.oecd-ilibrary.org/social-issues-migration-health/public-unemployment-spending/indicator/english_55557fd4-en?isPartOf=/ content/indicatorgroup/3ddf51bf-en, 10 IX 2014.

22 I. Berend, History Derailed. Central and Eastern Europe in the Long Nineteenth Century, Berkeley 2002, s. 200.

23 Tamże, s. 255.

24 M. Galent, P. Kubicki, New Urban Middle Class and National Identity in Poland, „Polish Sociological Review" 2012, nr 3. 
dóbr. Powszechny wzrost dobrobytu mierzony takimi wskaźnikami, jak posiadanie samochodu, telefonu komórkowego czy komputera, może nie oddawać faktycznych nastrojów społecznych i na pewno nie odzwierciedla kondycji społeczeństwa obywatelskiego, jego kapitału społecznego i poziomu zaufania. Karl Polanyi już w swoim klasycznym dziele z połowy XX w. zwracał uwagę na to, że Spoteczna destrukcja jest zjawiskiem gtównie kulturowym, a nie ekonomicznym i nie można jej zmierzyć za pomoca wysokości dochodu. [...] Nie ekonomiczna eksploatacja, jak się często zaktada, ale dezintegracja kulturowego środowiska eksploatowanych jest gtówna przyczyna degradacji [...] i polega raczej na eliminacji instytucji, $w$ których spoteczna egzystencja jest ucieleśniona, $[\ldots]$ chociaż standard życia [...] mógt się nawet podnieśs ${ }^{25}$.

To poczucie deprywacji może być tym większe, że podział na Polskę miejską i wiejską zaczął być również artykułowany coraz mocniej w przestrzeni publicznej. Z pewnością mamy tutaj do czynienia z formą przemocy symbolicznej dokonywanej poprzez dyskursywne praktyki stygmatyzacji społecznej. Jeden z najgłośniejszych przykładów to pogardliwe określenie „słoiki” na migrujących do stolicy Polaków. Za formami symbolicznymi idzie zwykła dyskryminacja. Tutaj chyba najbardziej jaskrawym przykładem jest sytuacja, w której dzieciom rodziców, którzy nie płacą podatków w miastach zamieszkania dzieci, odmawia się miejsc w przedszkolach. Praktyka sprzeczna z Kartą praw podstawowych Unii Europejskiej. Bardzo dwuznaczne etycznie są również kampanie prowadzone przez niektóre władze miasta z rektorami uczelni wyższych. Ich celem jest zachęcanie studentów do płacenia podatków w miastach, w których studiują. Rzesze studentów przywożą ze sobą na ogół olbrzymi kapitał finansowy wypracowany przez ich rodziców, a także otrzymują stypendia, na które składają się wszyscy obywatele płacący podatki w kraju. Namawianie ich zatem do tego, żeby redystrybuować pieniądze z ich peryferyjnych miejscowości do wielkomiejskich centrów, raczej nie wpisuje się w ideę solidaryzmu społecznego.

To w ogóle część szerszego zjawiska zdefiniowanego przez Michała Buchowskiego jako „orientalizacja à la polonaise”. Mechanizm ten opiera się na klasycznym koncepcie Edwarda Saida, twierdzącego, że stworzony na Zachodzie obraz Orientu nie opisuje realnego Wschodu, ale jest li tylko kulturowo skonstruowaną reprezentacją umożliwiającą tym, którzy posiadają władzę, legitymizować ich dominację nad podporządkowanymi. Zdaniem palestyńskiego intelektualisty taki instrument dyskursywny pozwala grupom politycznie silniejszym definiować grupy słabsze i przez to reprodukować pozycję hegemona $^{26}$. Koncepcję orientalizmu uzupełnia Buchowski mechanizmem opisanym przez Milicę Bakić-Hayden ${ }^{27}$ oraz Larry'ego Wolffa ${ }^{28}$, który polega na tym, że elity tych społeczeństw Europy Wschodniej, które w okresie Oświecenia zostały zdefiniowane przez

25 K. Polanyi, Great Transformation. The Political and Economic Origins of Our Times, Boston 2001, s. 164-167.

26 E. Said, Orientalism, New York 1979.

27 M. Bakić-Hayden, Nesting Orientalisms: The Case of Former Yugoslavia, „Slavic Review” 1995, Vol. 54, nr 4.

28 L. Wolff, Inventing Eastern Europe. The Map of Civilization on the Mind of the Enlightenment, Stanford 1994. 
Zachód jako zacofane i prymitywne, przejmują ten dyskurs, poddają się mu i na zasadzie kompensacji przedstawiają jako bardziej zacofane i prymitywne społeczeństwa położone jeszcze bardziej na wschód i południe.

Polski antropolog dodaje tutaj kolejny sposób orientalizowania, który nie wymiaru terytorialnego, ale społeczny, tzn. orientalizuje pewne kategorie społeczne w obrębie danego społeczeństwa. Stąd podtytuł jego artykułu: „od egzotycznego Innego do napiętnowanego brata”. Zdaniem Buchowskiego w przypadku orientalizacji à la polonaise takimi kategoriami byli na początku transformacji głównie jej przegrani, którym przypisano etykietkę homo sovieticus, niezależnie od tego, czy na to zasługiwali, czy nie. Łatwiej było przypisać im zacofanie i prymitywizm i tym samym obarczyć za to, że sobie nie poradzili, niż przyznać, że winne są również strukturalne determinanty uruchomione przez rewolucyjne zmiany, na które oni sami nie mieli większego wpływu.

Chociaż diagnoza Buchowskiego wydaje się w wielu miejscach przerysowana i niepotrzebnie przypisuje niektórym polskim intelektualistom złe intencje, to nie mam jednak wątpliwości, że mechanizm opisany przez niego ma całkiem sporą moc sprawcząą . Wydaje się, że dzisiaj często takim "egzotycznym Innym-stygmatyzowanym bratem” stają się właśnie mieszkańcy spoza wielkich centrów miejskich. „Słoiki” i „wieśniaki” to dzisiaj nierzadko ci, na których karb składa się przeróżne, często zupełnie oderwane od jakiegokolwiek logiki przyczynowo-skutkowej, niedostatki metropolitalnego życia. Jak ubodzy krewni lub niechciani intruzi zakłócają w wielu diagnozach polskie wysiłki zmierzające do okcydentalizacji. Oczywiście poczucie wyższości mieszkańców centrów w stosunku do prowincjuszy jest raczej zjawiskiem uniwersalnym, w Polsce jednak starcie pomiędzy Polską miejską i wiejską przybiera niekiedy formy narodowej obsesji.

Jedną z przyczyn powrotu do procesu dzisiejszej dualizacji społeczeństwa polskiego jest w moim głębokim przekonaniu, wypływającym się z wyników naszych badań terenowych, załamanie się społecznego wymiaru obywatelstwa w skali państwa. Nawiązując do przedstawionych wcześniej trzech rodzajów ryzyk, należy przypomnieć, że zabezpieczenie przed tymi ryzykami stanowią na ogół trzy zasadnicze instytucje: rodzina, rynek i państwo. W większości tradycyjnych społeczeństw agrarnych najważniejszą instytucją chroniącą jednostki przed niepożądanymi konsekwencjami braku pracy, złego zdrowia, wczesnego i podeszłego wieku oraz macierzyństwa/tacierzyństwa jest rodzina. W społeczeństwach industrializujących się, zindustrializowanych i postindustrialnych większą część zabezpieczeń przed ryzykiem przejmują rynek i państwo. Polska to w tej chwili społeczeństwo nierównego rozwoju, obok rzeczywistości społecznej niewiele odległej od społeczeństwa tradycyjnego mamy obszary społeczeństwa zindustrializowanego i postindustrialnego. Realizacja modelu obywatelstwa, w którym państwo radykalnie zredukowało swoją odpowiedzialność za jego społeczny wymiar, spowodowało, że w dużych aglomeracjach i z sukcesem reindustrializujących się mniejszych ośrodkach usługi i dobra zabezpieczające przed ryzykiem zaczęły być dostarczane głównie przez rynek. Mieszkania, niańki dla dzieci, żłobki, przedszkola, opiekunki dla starszych i chorych, wysokiej jakości opieka medyczna

29 M. Buchowski, The Specter of Orientalism in Europe... 
stają się relatywnie coraz bardziej dostępne. Głównym problemem jest kwestia możliwości zapłaty za te usługi. Ponieważ jednak w dużych aglomeracjach i prężnie rozwijających się mniejszych ośrodkach pracę można znaleźć znacznie łatwiej, a wynagrodzenie jest znacznie wyższe niż w wielu gminach położonych w regionach peryferyjnych, czyli w takich, jakie były przedmiotem naszych badań, wycofanie się państwa nie przyniosło tam tak druzgocącego efektu dla społecznego wymiaru obywatelstwa jak w regionach peryferyjnych.

Funkcjonowanie w złożonych społeczeństwach z efektywnie działającym sektorem rynkowym generalnie sprzyja większej otwartości na innych, stwarza szanse na szersze i bardziej zróżnicowane kontakty społeczne, daje możliwość bycia obecnym w wielu środowiskach. Co więcej, korzystanie z takich możliwości bardzo często jest dodatkowym atutem zwiększającym szanse na podnoszenie pozycji społecznej. Pomostowy kapitał społeczny może stać się łatwy do konwersji w innego rodzaju kapitały. Może przynieść awans w pracy, zatrudnienie w innej instytucji na lepszym stanowisku, nominację do roli społecznej o wysokim prestiżu, a tym samym przyczynić się podwyższenie statusu społecznego. Tym samym rodzina przestaje odgrywać kluczową rolę i następuje proces defamilizacji, czyli uniezależnienia się od więzi rodzinnych oraz przekształcenia ich w bardziej partnerskie relacje. Ponieważ usługi, które wcześniej realizowane były w gronie bliskich, oddelegowywane są coraz częściej na zasadach rynkowych nieznanym osobom, to jednocześnie pojawia się konieczność zbudowania zaufania do tych osób. Jest to mechanizm, który opisywałem szerzej w innym miejscu ${ }^{30}$. Brak elementarnego zaufania do innych utrudnia życie w złożonym społeczeństwie składającym się z wielu wyspecjalizowanych ról. Zaufanie czyni życie codzienne pod wieloma względami wygodniejszym. Dzięki temu poziom pomostowego kapitału społecznego rośnie. Rośnie również poziom kapitału łączącego, który decyduje o dystansie i współpracy ze strukturami instytucjonalnej władzy. Poruszanie się w przestrzeni indywidualnie konkurujących aktorów sprzyja kreowaniu zainteresowania sprawami publicznymi, bo to w przestrzeni publicznej wytwarzane są zasady, według których toczy się konkurencja. Im bardziej są one przejrzyste, czytelne i obiektywne, tym większe jest poczucie sprawiedliwości. Rynek niweluje również wpływ władzy politycznej na życie codzienne, w związku z czym łatwiej jest mobilizować zasoby społeczne w opozycji do instytucji władzy. Wiele wskazuje na to, że z takim właśnie mechanizmem mamy do czynienia $\mathrm{w}$ wielu polskich miastach, w których jesteśmy świadkami przebudzenia obywatelskiego i wysypu różnorakich ruchów społecznych ${ }^{31}$.

Niestety w regionach odległych od rozwijających się centrów funkcje ubezpieczeniowe państwa nie zostały zastąpione efektywnie działającym rynkiem. W poszukiwaniu bezpieczeństwa wielu mieszkańców badanych przez nas gmin musiało zwrócić się do innych instytucji zdolnych je zagwarantować. Tą instytucją jest na ogół rodzina.

30 M. Galent, Trust in the Everyday Life of Guests and Hosts: Employers and Employees in Belgium, „European Review” 2008, Vol. 16, nr 4, [online] http://dx.doi.org/10.1017/S1062798708000410.

31 Np.: L. Mergel, K. Pobłocki, M. Wudarski, Anty-bezradnik przestrzenny. Prawo do miasta w dziataniu, Warszawa 2013, Biblioteka Res Publiki Nowej. 
W przeciwieństwie do Polski wielkomiejskiej więzi rodzinne stały się tu ważniejsze i dlatego w tych społecznościach mamy do czynienia z procesem refamilizacji.

\section{STRUKTURALNE RAMY ORGANIZUJĄCE PROCESY REFAMILIZACJI}

W większości badanych przez nas gmin dominujący model gospodarstwa domowego przypomina sytuację skonceptualizowaną na gruncie tzw. nowej ekonomicznej teorii migracji zaproponowanej przez amerykańskich ekonomistów do opisu realiów krajów rozwijających się ${ }^{32}$. W tej perspektywie zwraca się uwagę nie na indywidualnych aktorów, ale właśnie na całe gospodarstwa domowe. Takie gospodarstwo domowe stanowi jednostkę, która dostarcza jej członkom pewnych usług i zasobów, ale wymaga również od nich odpowiedniego wkładu. W badanych przez nas miejscowościach to dość powszechna sytuacja. Typem idealnym byłby duży dom rodzinny zamieszkiwany przez trzypokoleniową rodzinę. W ramach tej rodziny najstarsze pokolenie otrzymuje renty lub emerytury, a także posiada skrawki ziemi, które udostępniane innym członkom rodziny gwarantują ubezpieczenia społeczne, a dzięki tym ubezpieczeniom członkowie ci mogą być superelastycznymi i supermobilnymi pracownikami. Kilka miesięcy w roku pracują sezonowo za granicą, kilka miesięcy pracują w Polsce, często na czarno, niektórzy ubiegają się o przyznanie pomocy społecznej. Dzięki takiemu zsumowaniu zasobów od wszystkich członków gospodarstwa możliwa jest w miarę znośna egzystencja, na tyle znośna, że nie skłania do emigracji osiedleńczej. Zbudowanie takiej współzależności jest z oczywistego względu pogłębiane przez wycofanie się państwa z funkcji zabezpieczyciela przed ryzykiem w sytuacji masowego bezrobocia przy jednoczesnym braku przejęcia tych funkcji przez rynek. Czyli to, co w miarę zadziałało w dużych metropoliach, generalnie wciąż nie działa w badanych przez nas społecznościach lokalnych. Pozostawieni sami sobie, mieszkańcy badanych przez nas regionów zwracają się w stronę najbliższych: rodziny, sąsiadów, przyjaciół.

Jak nie wyjechat za granice, to w tej miejscowości specjalizuje sięnp. w tynkarstwie. Jest samochód, cztery osoby do ktadzenia tynku, robienia wylewek. Samochód to zwykle podwójna kabina, z tytu plandeka i ciagnie na dwóch kótkach taki baniaczek. Ekipa tynkarska $z$ tym agregatem. Oni tym jeżdż i nawet daleko się wypuszczaja. Część zleceń biora na wtasna ręee, a cześśc zirm, np. Skanska. Jak maja prace, np. elewacje, tynki, wylewki czy coś, to podnajmuja firmę. Firma to jedna, dwie osoby i tych dwóch jest rolnikami, którzy mają pót hektara. A te pót hektara i tak dzierżawia (L/W/01).

Czy znane są panu przypadki, że ktoś wyjechat za granicę i wrócit na state?

Tutaj to sporadycznie, w mojej blizszej okolicy nie spotkatem się z tym. Choć sa przypadki, że inwestuja $w$ tym sensie, że zostawiaja rodziny i przeprowadzaja remonty, pomagaja rodzicom. Sa takie wsie wyludnione, gdzie się to zdarza, ocieplanie, poprawa otoczenia domu.

32 O. Stark, D.E. Bloom, The New Economics of Labour Migration, „American Economic Review” 1985, Vol. 75, nr 2. 


\section{Czy dużo osób $z$ regionu wyjeżd ża za granice za pracą?}

Jak dla mnie sporo. Troche wracaja, ale dużo zostaje. Mój syn siedzi teraz u Szwabów i nie jest mu źle. Powodzi mu się nawet jak na nasze standardy. Gdyby nie on, to bym tutaj sczezt jak pies jakiś. Za ta żatosna emeryturkę nic bym nie kupit. Przynajmniej z pomoca syna moge godnie żyć (NR/B/07).

Tak, dziewczyny z pracy jeżḋ̇a czasami do Holandii na ogórki, truskawki itd. Bez tego pewnie bytoby ciężko normalnie żyć. W szczególności jak mąż nie pracuje albo pije. Tutaj wielu ludzi tak funkcjonuje. Jak skończy się sezon, to tutaj nie ma co robić. Większość tych kwater sięzamyka na cztery spusty i wio na saksy albo na co tam. Częśc ma też ziemię, ale to té̇ nie wystarcza, żeby wyżywić rodzine (Z/Z/12).

Najbardziej to jest to przykre w takiej sytuacji, jak mam kolege, który ma trzy córki, wystudiowaty, dwie w AGH, jedna w Warszawie, i teraz gtowe sobie przesuszyć, jedna w Anglii, druga we Francji, jedna przy babce, druga w Anglii, to sa takie sytuacje. Jak ja bytem w Niemczech, to że ktoś pracuje w biurze czy coś, to sa gtęboko wybujane myśli. Jak bytem na fabryce BMW na kontrakcie, to w trakcie wakacji przyjeżdzaty nauczycielkiz naszych okolic, profesorki z uczelni i normalnie sprzataty na fabrykach, żeby dorabiać sobie. Tak że to dla nas też jest to trochę takie poniżajace. Tak jak teraz grupa policjantów pojechata do Szwecji przy krowach tam robić z naszych okolic. Jeżḋa tam do Szwecji po dziesięciu, zmieniaja się i co sobie o nas może tam pomyślé́, zatóżmy, ten Szwed? Stróż prawa jedzie krowy paść albo doić (L/P/02).

To tak, czesto też wysytaja pieniadze, żeby pomóc matkom, ojcom itd. To dobre dzieciaki, które zrobity to, co musiaty, żeby przeżyć. Nie ma co się dziwić. Jakbym miat sitę i może z 10 lat mniej, to sam bym wyjechat (NR/D/03).

UE data mi wiele pod względem możliwości wyjazdu. Bez emigracji nie przeżytbym. Nie bytbym w stanie zarobić na chleb. A tak, wyjechatem, zarobitem pieniadze, które później utrzymaty mnie na studiach. Jasne, nie byto tatwo, i zaczatem studia 3 lata później niż moi znajomi, ale takie jest życie. Nie wiadomo, jak moje losy by siępotoczyty, gdyby nie pieniadze zarobione w Wielkiej Brytanii. Może teraz bytbym spawaczem i Tusk bytby ze mnie dumny. Dla mnie byt to wyjazd gtównie po pieniadze. Nigdy nie chciatem tam zostać i pracowaćjako pomywacz i kierowca. Potrzebowatem środków, żeby później wrócić do Polski i utrzymać sie na aplikacji radcowskiej. Tak też zrobitem. [...] Bez zmian. Emigracja w tym regionie jest czymś tak naturalnym, że ludzie w sumie dziwia się, jeżeli ktoś jeszcze nie wyjeżdzat (L/BK/02).

To na pewno duże udogodnienie dla nas. Duża grupa ludzi mtodych wtaśnie z tego powodu nie chciataby opuszczać Unii. Nie oszukujmy się, ta nasza migracja jest gigantyczna. Ta wschodnia czéść Polski poza tym, że sq emerytury, że jest w rodzinie „dziadek utrzymujacy" i ma staty dochód, to podstawa utrzymania sa sezonowe wyjazdy. I $z$ tego tutaj ludzie $\dot{z y j a}(\mathrm{Z} / \mathrm{Z} / 03)$.

\section{Czy mieszkańcy gminy wyjeżḋają za granicę?}

Tak, masowo. Za chlebem. Przecież bezrobocie $w$ tym miejscu jest tak wysokie, że nic innego nie pozostaje. Ewentualnie strzelić sobie $w$ teb. Emigracja $w$ tym regionie to już część kultury. Strasznie dużo rodzin ma kogoś za granica. Później ściagaja siebie nawzajem. Mtodzi czasami wracaja, bo studia albo coś innego, ale zazwyczaj już tam sięzostaje. Nikt nie chce tutaj wracać, bo naprawdę nie ma do czego (L/G/01). 
Ta superelastyczność i supermobilnośc wynika z kolei z dualizacji rynku pracy. Sama koncepcja dualizacji rynku pracy stworzona została w 1971 r. przez amerykańskich ekonomistów Doeringera i Priora, którzy prowadzili badania nad migracjami. Opisali oni w ten sposób sytuację, w której, mówiąc najogólniej, imigranci zatrudniani są na znacznie gorszych warunkach niż ludność tubylcza. Tym sposobem na rynku pracy wykształcają się dwa segmenty. Jeden jest lepszy, daje lepsze gwarancje bezpieczeństwa i zarezerwowany jest dla pewnej określonej kategorii pracowników. Drugi jest gorszy, i przeznaczony dla tych, którzy ze względu na swoje cechy, nie zawsze merytoryczne, nie są dopuszczani do pierwszego ${ }^{33}$. Kategoria dualizmu rynku pracy jest obecnie coraz częściej używana do opisu nie tylko w kontekście migracji, ale w ogóle do opisu segmentalizacji rynków pracy.

Jak wynika z obserwacji badanych przez nas lokalnych społeczności, ten dualizm bierze się stąd, że mamy w tych społecznościach bardzo często do czynienia z sytuacją, w której monopolistycznym pracodawcą są lokalne władze. Kontrolują one większość etatów dających stabilność i bezpieczeństwo zatrudnienia. Poza nimi działają co prawda prywatni pracodawcy, ale z powodu niemal monopolistycznej pozycji, wynikającej z wysokiego bezrobocia, oferują najgorsze z możliwych warunków pracy. Zatrudnienie oferowane w małych prywatnych firmach oznacza bardzo często nie tylko brak minimalnych standardów, jak minimalna pensja, ale też w ogóle pracę na czarno, bez opłacania składek i podatków, nie wspominając już o innych formach ochrony pracownika. Jak wynika z naszych badań, taka sytuacja w niektórych regionach jest powszechna. W jednej z badanych przez nas gmin jeden sołtys przyznał, że w jego wsi w co najmniej $90 \%$ gospodarstw domowych przynajmniej jedna osoba pracuje na czarno, w dwóch innych sołtysi ujawnili, że proceder ten jest obecny w co najmniej $50 \%$ gospodarstw. Wszyscy trzej sołtysi przyznali, że sami również pracują na czarno.

W związku z transferem poważnych środków na inwestycje powstają również często sytuacje, w których lokalne władze zdobywają pozycję monopsonu w stosunku do jednej z najlepiej rozwiniętych branż w lokalnych ośrodkach, czyli budowlance. Monopson polega na tym, że jeden główny odbiorca towarów czy usług poprzez swoją dominującą pozycję na rynku może narzucać kontrahentom własne warunki. Pozycja monopsonu, jaką zajmują samorządy w środowiskach lokalnych, powoduje, że oprócz kontroli, jaką posiadają nad rynkiem pracy objętym ich zakresem władzy, posiadają również dodatkowo pośrednią kontrolę nad tym, kogo i na jakich warunkach zatrudniają prywatni przedsiębiorcy. Taki splot wpływu władzy na lokalny rynek pracy i utrzymującego się wysokiego bezrobocia powoduje, że rzadko kto wierzy w merytokratyczne zasady zatrudnienia i zdobywania zamówień publicznych. Opinia o tym, że konkursy na stanowiska pracy i przetargi na wykonanie inwestycji są bardzo często fikcyjne, jest dosyć powszechna.

$Z$ tymi urzędasami to nigdy nic nie wiadomo. Pewnie jakiśsynek, córeczka, kuzyneczka, bratanica wójta. Bo tutaj tak to jest. Uktad, Panie. Nie ma mowy, żeby ktośw urzedzie, co ja mówię, bibliotece dostat pracę bez btogostawienstwa góry. Raczka raczkę myje (L/G/04).

33 M.J. Piore, Birds of Passage. Migrant Labor and Industrial Societies, Cambridge-New York 1979. 
Czy wedtug Pana Polacy chcący wykorzystać możliwości ptynące z integracji europejskiej moga liczyć na pomoc państwa i wtadz lokalnych?

Moga tyko ci, którzy należa do partii lub uktadu, który rządzi tutaj lokalnie. Cata reszta jest sukcesywnie odcinana (L/G/06).

Czy uważa Pan, że sa firmy bardziej lub mnie faworyzowane przy takich przetargach?

$Z$ decydowanie. Sa to firmy bezpośrednio potaczone z wójtem. Jak widzi Pan, u nas dużo rzeczy się odnawia, renowuje, więc wiadomo, o co chodzi (L/G/08).

Mam ten sklep, ale szukam pracy w zawodzie. Ukończytam Wydziat Prawa i Administracji we Wroctawiu, ale nie ma szans na pracę w zawodzie, a już zpewnościa nie tu. Tu na poziomie lokalnym decyduja tylko znajomości, nic więcej. Byty wprawdzie parę lat temu regulacje dotyczace tego, że do pracy w danych urzędach niezbędne jest wyższe wyksztatcenie, ale i to obchodzono. Ktośskończyt geografię na przyktad i pracuje w skarbówce (NR/J/05).

Dualizm rynku pracy polega więc na tym, że posiada się kontakty, znajomości, jest się lojalnym klientem politycznego lub urzędniczego patrona i głównie dzięki temu ma się szansę na znalezienie zatrudnienia. A jeśli nie, to jest się poza siecią znajomości i przez to szanse na znalezienie pracy i stałe zatrudnienie są znikome. Oczywiście taka sytuacja nie jest bezwyjątkową normą. Wiele osób twierdziło, że zajęły swoje stanowisko w normalnym konkursie, bez tzw. pleców. Powszechne wyobrażenie społeczne jest jednak zupełnie inne. Efektem takiej dualizacji jest powstawanie sieci klientelizmu i wzrost społecznej nieufności, które z kolei są dysfunkcjonalne dla społeczeństwa obywatelskiego i w ogóle dla demokratycznych instytucji. Uwikłani w przeróżne zależności mieszkańcy badanych przez nas gmin dosyć dobrze identyfikowali porządek dziobania i byli bardzo świadomi wielu patologii z takiego stanu rzeczy wynikających.

Jeden z sołtysów wyjaśniał specyfikę takiej atmosfery społecznej:

Część osób nie przyznaje się do tego, że należy czy popiera jakąśsartię. To jest mate środowisko, tutaj każdy każdego zna. I teraz zatóżmy: jestem sympatykiem np. PO, a żona będzie pracowata $w$ gospodarstwie komunalnym, w którym zarządzający jest sympatykiem PiS. Nikt się nie przyznaje, ludzie to sobie kalkuluja. Myśle, że wiem, co mówię, bo rozmawiam z ludźmi. Woli się nie przyznawać, nie tylko do przynależności partyjnej, ale nawet do inwestycji przez gmine prowadzonych. Mówi mi taka znajoma nauczycielka. Oficjalnie przytaknie, bo jest moda np. na Orlik. Ale ma nad soba dyrektora, a maż pracuje $w$ firmie komunalnej, to lepiej, żeby nie wypowiadać się na taki temat. Prywatnie tak, ale oficjalnie już nie (L/W/01).

Przy czym rzeczą niezwykle charakterystyczną jest to, że nasi respondenci niemal nigdy nie podważali samej idei demokracji i nie domagali się rządów silnej ręki. Wręcz przeciwnie, to, na co narzekali, to brak właściwie funkcjonujących mechanizmów demokratycznych: brak demokracji, oligarchiczny charakter lokalnej władzy, układy, nepotyzm, korupcja, upartyjnienie urzędów, funkcji, kryteriów kooptacji do miejscowej elity.

Powracając do naszych badań w tych środowiskach sprzed piętnastu lat ${ }^{34} \mathrm{i}$ aparatury pojęciowej konceptualizującej zmienne opisujące postawy wobec integracji europejskiej,

34 M. Galent, M. Natanek, E. Turyk, Interesy, szanse izagrożenia, kompetencje cywilizacyjne apostawy wobec integracji europejskiej, [w:] Polska lokalna wobec integracji europejskiej, red. Z. Mach, D. Niedźwiedzki, Kraków 2001, s. 125-172. 
można by rzec, że poziom kompetencji cywilizacyjnych ${ }^{35}$ wśród mieszkańców badanych przez nas gmin radykalnie wzrósł, w tym sensie, że wartość demokracji jako sposobu na najlepsze rządy została dosyć powszechnie zinternalizowana. Pod tym względem różnica w kompetencjach do życia w europejskim społeczeństwie mieszkańców w badanych gminach $\mathrm{w}$ porównaniu $\mathrm{z}$ badaniami przeprowadzonymi piętnaście lat temu była olbrzymia ${ }^{36}$. Tym razem to nie demokracja stanowiła problem, ale raczej jej wypaczone formy.

Można krytykować, opisywać, mamy gazety lokalne, ale tu się bardziej tych ludzi pilnuje, i oni się licza, chociaż powiem Wam, że wydaje mi się, że ci komuniści, wielcy dyrektorzy w PRL-u, to bardziej przed ludźmi się wstydzili swoich kantów, nieuczciwości, niż $w$ tej chwili. Obecnie to nie ma żadnych takich zasad, ukradtem, to ukradtem, nie wstydze sie, zrobitem świństwo koledze, tez się nie wstydzę, bo ja muszę żyć. Zrobity się takie nieciekawe historie. Ja tu raczej górę krytykuje, bo ona daje zty przyktad, po prostu. Nie liczy się z ludżmi, nieważne referenda, nieważne podpisy, ja nie wiem, co to za demokracja jest (NR/L/05).

\section{Czy bierze Pani udziat w wyborach samorzadowych, czynnie i biernie?}

Zawsze gtosuje, ale nigdy nie będę kandydować. Koleżanka kandydowata do rady miasta, przegrata i chwile później stracita pracę w urzędzie powiatowym. Dziękuję za coś takiego (L/G/01).

\section{Jak wedtug Pani wypadamy w porównaniu z np. Austriakami?}

O Jezu, wie Pan, czego mi najbardziej brakuje w Polsce? Myślenia, logiki. Tam wszystko byto i jest logiczne, proste, dla ludzi. Tam państwo i samorzą, urzędy maja świadomość, że są, by stuzyć ludziom, ale w tym pozytywnym znaczeniu tego stowa. Jak ja tutaj idę do urzędu, to później przez tydzień mam depresję. To jest dla mnie doświadczenie traumatyczne. [...] Osobiście uważam, że cata gmina powinna pójść do zmiany sktadu. Wszyscy. A jak nie, to przynajmniej do jakiejś okresowej rewizji. Powinny pojawić się osoby z jakimśświeższym spojrzeniem na zarządzanie, powinien być ktoś mtodszy. Tutaj ci wszyscy ludzie robia doktadnie to, co robili za komuny, oni nie potrafia inaczej i tyle. Nowych sztuczek już ich się nie nauczy. To jest cata świta, który siedzi tam nie wiadomo ile lat, to wszystko jest skupione wokót jaśnie nam panującego XXX i chyba to cate towarzystwo czuje sięnieco zbyt bezpiecznie (Z/B/02).

Ja mówitem, oni się wszyscy tam konsultuja sami ze soba, jak w przypadku XXX, szkoda gadać. Nie ma żadnej wspótpracy, żadnych rozmów, nic. Tu w ogóle nie ma mowy o żadnej demokracji na szczeblu gminy, jedna klika przez tyle lat i tyle (Z/G/01).

Każdy by chciat coś uzyskać, ale po cichu, nie narażajac się. A ponieważ ja jestem jakoś tam osoba chroniona, powiedzmy, no to idź powiedz, idź zatatw, albo masz więcej odwagi itd. Ale to sie w cztowieku kumuluje, reperkusje pewnych zachowań cztowiek zbiera, to nie jest tak, że tak jak sie opowiada na lekcjach, że tak jest demokracja, jest różnica zdań, trzeba wszystko powiedzieć, my to akceptujemy, nie można konsekwencji wyciagać. No ja na

35 P. Sztompka, Civilizational Incompetence. The Trap of Post-communist Societies, „Zeitschrift für Soziologie" 1993, Vol. 22, nr 2.

36 Polska lokalna wobec integracji... 
swoich czynach, na swojej osobie takich konsekwencji doświadczytam i tak jak rozmawiam zinnymi zwiąkowcami $w X X X$, to jednak dużo osób po prostu się boi. No są takie sytuacje, $\dot{z}$ e wtadza nie chce z nami rozmawiać (SZ/SZ/04).

Czy uważa Pan, że konsultacje sq waznym instrumentem $w$ tworzeniu prawa?

Tak, oczywiście, niestety niewykorzystywanym. Ludzie na konsultacje nie wychodza. Nie chce im sięczy się boja. To jest mate środowisko i boja się napiętnowania, boja się o pracę. I jak tak nie chodza, to wtadza nie ma powodu, żeby zwotywać takie posiedzenia, no i umiera to troche śmiercia naturalna (L/G/08).

No ja jestem rozgoryczona, muszępowiedzieć. No bo jak tak nastat ten nowy burmistrz, zwtaszcza że to jest mój byty dyrektor, którego zawsze cenitam, no ale jak to się mówi, punkt widzenia zależy od punktu siedzenia. Troche się pewnie zmienia perspektywa widzenia problemu, ja pewnie widze z jednej strony, ale też nigdy nie ma jakiejś dyskusji, zaproszenia do podzielenia się uwagami, to jest zawsze takie kazanie. A wy jak nie będziecie podskakiwać, to może będziecie mieli spokój. [...] No mówię, tutaj nikt nie zabiera gtosu, nikt się nie odzywa, nie ma jakiejkolwiek krytyki. Ja Panu powiem, że ja zagtosowatam przeciwko zmianie systemu oceniania, bo uważatam, że koncepcja jest niedobra, podobat mi się stary system. I ja dostatam uwage, jak ja moge gtosować przeciwko pani dyrektor. I takie sq czasy. To byto niemile widziane, to byto faux pas. Bytam zdziwiona, bo nie gtosowaliśmy, czy ja lubie czy nie lubie, czy do nagrody czy medalu, do Bóg wie czego (SZ/SZ/04).

Wie Pan, co jest najgorsze, ludzie nie potrafia się zmobilizować i coś zmieniać. Jest coś, jakieś prawo, rozporządzenie, które zostato ustanowione przez jakiegoś kolesia, któremu ewidentnie posmarowano albo miat $w$ tym jakiś interes. Ludzie o tym wiedza, ale nic nie robia. Nie wierza, że sq w stanie coś zmienić, bo rozbija się o biurokracje albo jeszcze ktoś będzie się na nich mścit, albo jeszcze może być taka sytuacja, że będzie wytykany palcami w tak matej miejscowości jak ta $(\mathrm{Z} / \mathrm{B} / 02)$

Młody człowiek po kilku latach zaangażowania politycznego przyznaje z rozczarowaniem:

\section{Pan jest cztonkiem jakiejśpartii politycznej?}

Jestem, jestem. To znaczy jeszcze jestem, ale tak kiedyśkolega z sasiedniej placówki kulturalnej zachęcit mnie, żebym się zapisat do PO, i jestem cztonkiem, chociaż od iluśjuż lat noszę się z zamiarem wypisania się, bo mówię, w momencie powstawania PO te huczne hasta i to wszystko, co oni mówili i co byto przekazywane, to jako mtodego chtopaka to jakoś mnie to zainteresowato, ale w perspektywie czasu zobaczytem te mechanizmy dziatalności i jak to sie wszystko przedstawia i na jakich zasadach to dziata, że wszędzie rzaddza uktady, jakieś takie przepychanki personalne. I to mnie bardzo przestraszyto, że ta partia wniczym nie różni się od innych, a wręcz można powiedzieć, że jest jeszcze gorzej. Dlatego jestem zdystansowany i myśle, że to jest btad życiowy, który popetnitem. To w sumie pod wptywem kolegi, który prowadzi podobna dziatalność w Polanicy, to pod jego wptywem, za jego namowa przystąitem, ale jestem rozgoryczony tym, co się dzieje (SZ/SZ/01).

W przeciwieństwie do dużych miast, gdzie rynek coraz sprawniej pełni funkcję ubezpieczyciela, mieszkańcy małych społeczności lokalnych zacieśniają relacje w grupach pierwotnych i to w nich właśnie budowane i reprodukowane jest zaufanie. Ponieważ podstawową grupą pierwotną jest rodzina, następuje proces refamilizacji. To, co 
jest najważniejsze i najistotniejsze dla bezpieczeństwa jednostki, ulokowane jest w rodzinie i grupie pierwotnej, dlatego to, co na zewnątrz, traktowane jest jako rzecz nieswoja, teren do eksploatacji, obszar natury, do którego wyrusza się po to, żeby zdobyć zasoby, a potem dostarczyć je do domu. W sytuacji, kiedy lokalne kanały pionowej mobilności społecznej są zablokowane, uruchomiona musi być mobilność pozioma. Sezonowe opuszczanie własnej miejscowości i kontekstu społecznego, w którym respektuje się normy, pozwala na prowadzenie "gospodarki rabunkowej” poza kręgiem społecznym uznawanym za własny. Takie zdystansowane traktowanie otoczenia przez wyruszających z domu po zarobek doskonale można uchwycić w przypadku wielu migrantów wahadłowych, którzy przebywając w nowym miejscu zamieszkania, mniej lub bardziej tymczasowego, pełną swoją energię poświęcają akumulacji wymiernych korzyści wynikających z emigracji, nie zawsze troszcząc się o zachowanie społecznych i kulturowych standardów wobec ludności tubylczej czy innych migrantów. Tego typu strategie migracyjne opisywaliśmy szerzej w innym miejscu ${ }^{37}$.

To, co jest jednak ważne w kontekście tej pracy, to fakt, że takie postępowanie jest z perspektywy refamilizowanych więzi społecznych jak najbardziej racjonalne. Czy to we własnym regionie, czy to opuszczając go, superelastyczni pracobiorcy kierują się głównie interesem swojego gospodarstwa domowego, dlatego jak piszą autorzy klasycznej pracy na temat zaufania w relacjach klientystycznych Samuel N. Eisenstadt i Luis Roniger: Relacje pomiędzy jednostkami i sieciami budowane sq raczej $w$ wertykalny sposób [...], a nie pomiędzy zorganizowanymi zgodnie z ich interesem grupami; powoduje to zmniejszenie znaczenia horyzontalnych powiazań i solidarności ${ }^{38}$. Jak wskazuje Nan Lin, w sytuacji kiedy sieć kontaktów jest już ustanowiona, na ogół następuje wtedy faza zamknięcia i ochrony przed innymi potencjalnymi partnerami interakcji. Bliskość i gęstość takich relacji jest znacznie ważniejsza od otwartości ${ }^{39}$. Szerszy interes społeczny najpierw znika z horyzontu doświadczeń, a potem z katalogu wartości.

Tym sposobem rodzaj dominującego kapitału generowanego przez proces refamilizacji ma zdecydowanie wiążący charakter. Działanie w takich strukturalnych warunkach nie wymusza również zbliżenia do władzy czy chęci wpływania na nią. Superelastyczność zatrudnienia w badanych przez nas przypadkach często polega na omijaniu lub naginaniu oficjalnych reguł. Często też koncentruje się w niszach, w których można uniknąć płacenia podatków i innych danin społecznych. Przy braku gwarancji minimalnego bezpieczeństwa socjalnego na ogół zresztą nie ma wyboru. Zarówno patronowi, jak i klientowi nie zależy na tym, żeby ktoś z zewnątrz interweniował w ich obustronne umowy, ponieważ cechą tych umów jest maksymalizacja i prywatyzacja zysków przy jednoczesnym przerzucaniu zewnętrznych kosztów transakcji na innych. Przez to starają się trzymać z dala od struktur władzy, a tym samym wpływają niekorzystnie na

37 M. Galent, I. Goddeeris, D. Niedźwiedzki, Migration and Europeanisation. Changing Identities and Values of Polish Pendulum Migrants and their Belgian Employers, Kraków 2009, s. 73-77.

38 S.N. Eisenstadt, L. Roniger, Patrons, Clients and Friends. Interpersonal Relations and the Structure of Trust in Society, Cambridge 1984, s. 48-49, Themes in the Social Sciences.

39 N. Lin, Social Capital. A Theory of Social Structure and Action, Cambridge-New York 2001, s. 27, Structural Analysis in the Social Sciences, 19. 
łączący wymiar kapitału społecznego. Zaufanie do własnego społeczeństwa, władz lokalnych i centralnych słabnie, bo praktycznie znikają one z codziennych doświadczeń superelastycznych pracobiorców i ich patronów. Z powodu bardzo dużej mobilności zdarza im się nierzadko wpadać w pułapkę „podwójnej nieobecności”, o czym pisałem już wcześniej w innym miejscu ${ }^{40}$. Migrując ustawicznie za chlebem, tracą więzi z własną społecznością lokalną i na ogół nie mają możliwości, a często też chęci, żeby żyć sprawami społeczności goszczących.

W miejsce państwa i lokalnej wspólnoty pojawił się europejski rynek pracy. Polskie państwo przestało gwarantować minimum bezpieczeństwa, a słaby rynek, w przeciwieństwie do dużych miast, nie jest w stanie tego braku państwa wypełnić. W tych warunkach ratunkiem stała się Unia Europejska. Jako że niemal we wszystkich wywiadach kojarzona jest z możliwością swobodnego przekraczania granic i legalnym zatrudnieniem w innych państwach, to dla wielu Polaków i ich rodzin Unia Europejska stała się nie tylko gwarantem egzystencji, lecz także szansą na realizację wielu indywidualnych planów życiowych. Niestety, ten wzrost zaufania do Unii Europejskiej nie kompensuje poczucia rozczarowania z powodu zrzeczenia się odpowiedzialności państwa za taki kształt rzeczy w naszym kraju. Zdaniem jednego z respondentów:

Jak panstwo przestaje opiekować się wtasnym obywatelem, mtodym obywatelem, to tak troche go wydala. Na zasadzie „idź sobie szukać pracy gdzie indziej, bo tutaj już nie jesteś potrzebny". To co ma sobie pomyśleć taki mtody cztowiek. Jedzie na Wyspy i tam znajduje nowe rzeczy. Może nie staje się Brytyjczykiem, ale na pewno nie jest Polakiem. Wydaje mi się, że mtodzi ludzie sa permanentnie źli. I to nam się kiedyś odbije (Z/Z/10).

\section{BIBLIOGRAFIA}

Bakić-Hayden M., Nesting Orientalisms: The Case of Former Yugoslavia, „Slavic Review” 1995, Vol. 54, nr 4 .

Beck U., Spoteczeństwo ryzyka. W drodze do innej nowoczesności, przeł. S. Cieśla, Warszawa 2004, Spoteczeństwo Wspótczesne.

Berend I., History Derailed. Central and Eastern Europe in the Long Nineteenth Century, Berkeley 2002.

Bourdieu P., The Forms of Capital, [w:] Handbook of Theory and Research for the Sociology of Education, red. J. Richardson, New York 1986.

Buchowski M., The Specter of Orientalism in Europe: From Exotic Other to Stigmatized Brother, „Anthropological Quarterly” 2006, Vol. 79, nr 3, [online] http://dx.doi.org/10.1353/ anq.2006.0032.

CBOS, Komunikat z badań, BS/33/2012, Zaufanie spoteczne, Warszawa, III 2012.

Coleman J., Social Capital in the Creation of Human Capital, „American Journal of Sociology” 1988, Vol. 94, Supplement, [online] http://dx.doi.org/10.2307/2780243.

40 M. Galent, Kapitat spoteczny polskich migrantów w Belgii, czyli jak uniknąć putapki „podwójnej nieobecności", [w:] Wspótczesne polskie migracje. Strategie, skutki, reakcja państwa, red. M. Lesińska, M. Okólski, Warszawa 2013, Studia Migracyjne. 
Czapiński J., 6.3. Kapitat spoteczny, „Conterporary Economics” 2013, Vol. 7, Special Issue: Diagnoza spoteczna 2013. Warunki i jakość życia Polaków, s. 285, [online] http://dx.doi. org/10.5709/ce.1897-9254.110.

Eisenstadt S.N., Roniger L., Patrons, Clients and Friends. Interpersonal Relations and the Structure of Trust in Society, Cambridge 1984, Themes in the Social Sciences.

Esping-Andersen G., Spoteczne podstawy gospodarki postindustrialnej, przeł. R. Włoch, Warszawa 2010, Wspótczesna Polityka Spoteczna.

Esping-Andersen G., The Three Worlds of Welfare Capitalism, Princeton 1990.

Fukuyama F., Zaufanie. Kapitat spoteczny a droga do dobrobytu, przeł. A. i L. Śliwa, WarszawaWrocław 1997.

Galent M., Kapitat spoteczny polskich migrantów w Belgii, czyli jak uniknąć putapki „podwójnej nieobecności", [w:] Wspótczesne polskie migracje. Strategie, skutki, reakcja państwa, red. M. Lesińska, M. Okólski, Warszawa 2013, Studia Migracyjne.

Galent M., Trust in the Everyday Life of Guests and Hosts: Employers and Employees in Belgium, „European Review” 2008, Vol. 16, nr 4, [online] http://dx.doi.org/10.1017/S106 2798708000410.

Galent M., Goddeeris I., Niedźwiedzki D., Migration and Europeanisation. Changing Identities and Values of Polish Pendulum Migrants and their Belgian Employers, Kraków 2009.

Galent M., Kubicki P., New Urban Middle Class and National Identity in Poland, „Polish Sociological Review” 2012, nr 3.

Galent M., Natanek M., Turyk E., Interesy, szanse i zagrożenia, kompetencje cywilizacyjne a postawy wobec integracji europejskiej, [w:] Polska lokalna wobec integracji europejskiej, red. Z. Mach, D. Niedźwiedzki, Kraków 2001.

Giddens A., Stanowienie spoteczeństwa. Zarys teorii strukturacji, przeł. S. Amsterdamski, Poznań 2003.

Giddens A., Życie w spoteczeństwie posttradycyjnym, [w:] U. Beck, A. Giddens, S. Lash, Modernizacja refleksyjna. Polityka, tradycja i estetyka w porządku spotecznym nowoczesności, przet. J. Konieczny, Warszawa 2009, Socjologia Wspótczesna.

Halman L., Luijkx R., Social Capital in Contemporary Europe: Evidence from the European Social Survey, „Portuguese Journal of Science” 2006, Vol. 5, nr 1, [online] http://dx.doi. org/10.1386/pjss.5.1.65/1.

Halpern D., Social Capital, Cambridge 2005.

Kołodziej J., Świadomość i rozumienie wartości europejskich w polskim społeczeństwie. Niepublikowane wystąpienie w ramach I Ogólnopolskiego Kongresu Europeistyki „Polska w procesie integracji europejskiej - dekada doświadczeń”, Warszawa, 18-20 IX 2014.

Kurczewski J., Cichomski M., Wiliński K., Wielkie bazary warszawskie. Środowisko spoteczne, kultura i problem spoteczny, Warszawa 2010, Obyczaje, Prawo i Polityka, Życie Codzienne.

Lin N., Social Capital. A Theory of Social Structure and Action, Cambridge-New York 2001, Structural Analysis in the Social Sciences, 19.

Lokalne wzory kultury politycznej. Szkice ogólne i opracowania monograficzne, red. J. Kurczewski, Warszawa 2007.

Mann M., The Sources of Social Power, t. 4: Globalizations, 1945-2011, Cambridge 2013. 
Marshall T.H., Citizenship and Social Class, [w:] Citizenship. Critical Concepts, red. B. Turner, P. Hamilton, London-New York 1994.

Mergel M., Pobłocki K., Wudarski M., Anty-bezradnik przestrzenny. Prawo do miasta w dziataniu, Warszawa 2013, Biblioteka Res Publiki Nowej.

Oblicza lokalności. Tradycja i wspótczesność, red. J. Kurczewska, Warszawa 2006.

Obszary tadu i anomii. Konsekwencje i kierunki polskich przemian, red. A. Miszalska, A. Piotrowski, Łódź 2006.

OECD, Public unemployment spending. [online] http://www.oecd-ilibrary.org/social-issues-migration-health/public-unemployment-spending/indicator/english_55557fd4-en? isPartOf=/content/indicatorgroup/3ddf51bf-en.

Pierwsza dekada niepodlegtości. Próba socjologicznej syntezy, red. E. Wnuk-Lipiński, M. Ziółkowski, Warszawa 2001.

Piore M.J., Birds of Passage. Migrant Labor and Industrial Societies, Cambridge-New York 1979.

Polanyi K., Great Transformation. The Political and Economic Origins of Our Times, Boston 2001.

Polska lokalna wobec integracji europejskiej, red. Z. Mach, D. Niedźwiedzki, Kraków 2001.

Powiatowa elita polityczna. Rekrutacja, struktura, dziatanie, red. J. Wasilewski, Warszawa 2006.

Putnam D.R., Bowling Alone. The Collapse and Revival of American Community, New York 2000.

Putnam D.R., Demokracja w dziataniu. Tradycje obywatelskie we wspótczesnych Wtoszech, przeł. J. Szacki, Kraków 1995, Demokracja.

Said E., Orientalism, New York 1979.

Socjologia pojednania, red. J. Kurczewski, Kraków 2012, Seria Wydawnicza Polskiego Towarzystwa Socjologicznego.

Sowa J., Fantomowe ciato króla. Peryferyjne zmagania z nowoczesną formą, Kraków 2011, Horyzonty Nowoczesności, 90.

Stark O., Bloom D.E., The New Economics of Labour Migration, „American Economic Review” 1985, Vol. 75, nr 2.

Swianiewicz P. i in., Szafarze darów europejskich. Kapitat spoteczny a realizacja polityki regionalnej w polskich województwach, Warszawa 2008.

Sztompka P., Civilizational Incompetence. The Trap of Post-communist Societies, "Zeitschrift für Soziologie" 1993, Vol. 22, nr 2.

Sztompka P., Trauma wielkiej zmiany. Spoteczne koszty transformacji, Warszawa 2000.

Sztompka P., Zaufanie. Fundament spoteczeństwa, Kraków 2007.

Trzy Polski. Potencjat i bariery integracji z Unia Europejska. EU-monitoring III, red. J. Hausner, M. Marody, Warszawa 1999.

Wojakowski D., Swojskość i obcość w zmieniającej się Polsce, Warszawa 2007.

Wolff L., Inventing Eastern Europe. The Map of Civilization on the Mind of the Enlightenment, Stanford 1994.

Wyciskanie brukselki? O europeizacji spoteczności lokalnych na pograniczach, red. J. Kurczewska, H. Bojar, Warszawa 2009.

Ziółkowski M., Przemiany interesów i wartości spoteczeństwa polskiego. Teorie, tendencje, interpretacje, Poznań 2000. 
Dr Marcin GALENT - socjolog, pracuje jako adiunkt w Instytucie Europeistyki Uniwersytetu Jagiellońskiego. Prowadził badania m.in. w Globalnym Centrum Doskonałości Uniwersytetu w Osace, na Uniwersytecie w Leuven, Uniwersytecie w Getyndze, London School of Economics and Political Science, Uniwersytecie w Cambridge i Uniwersytecie w Oksfordzie. Jego główne zainteresowania to migracje, wielokulturowość i obywatelstwo w Europie. Ostatnio zajmuje się również historią i teorią państwa dobrobytu. 